\title{
Author Correction: hnRNP H/F drive RNA G- quadruplex-mediated translation linked to genomic instability and therapy resistance in glioblastoma
}

\author{
Pauline Herviou, Morgane Le Bras, Leïla Dumas, Corinne Hieblot, Julia Gilhodes, Gianluca Cioci, \\ Jean-Philippe Hugnot, Alfred Ameadan (D), François Guillonneau (D), Erik Dassi (D), Anne Cammas (1D) \& \\ Stefania Millevoi (1)
}

Correction to: Nature Communications https://doi.org/10.1038/s41467-020-16168-x, published online 27 May 2020.

The original version of this Article contained an error in the "Methods" section, which incorrectly omitted at the start of the "GBM tumour sample" paragraph the following information and reference to previous work: "The used protein extracts derived from both low and high grade gliomas were originally processed and used in the article from from Pr JP Hugnot's lab ${ }^{68}$ ". Additionally, the original version of this Article omitted the reference 68 to the previous work in "Leventoux N, Augustus M, Azar S, et al. Transformation Foci in IDH1-mutated Gliomas Show STAT3 Phosphorylation and Downregulate the Metabolic Enzyme ETNPPL, a Negative Regulator of Glioma Growth. Sci Rep. 2020;10(1):5504. Published 2020 Mar 26. https://doi.org/10.1038/s41598-020-62145-1". This has been added as a reference 68 in the newly corrected paragraph in the "Methods" section under "GBM tumour sample". These have been corrected in both the PDF and HTML versions of the Article.

Published online: 12 May 2021

\footnotetext{
(c) (i) Open Access This article is licensed under a Creative Commons Attribution 4.0 International License, which permits use, sharing, adaptation, distribution and reproduction in any medium or format, as long as you give appropriate credit to the original author(s) and the source, provide a link to the Creative Commons license, and indicate if changes were made. The images or other third party material in this article are included in the article's Creative Commons license, unless indicated otherwise in a credit line to the material. If material is not included in the article's Creative Commons license and your intended use is not permitted by statutory regulation or exceeds the permitted use, you will need to obtain permission directly from the copyright holder. To view a copy of this license, visit http://creativecommons.org/licenses/by/4.0/.
}

(C) The Author(s) 2021 